\title{
The Next Pharmaceutical Path: Determining Technology Evolution in Drug Delivery Products Fabricated with Additive Manufacturing
}

\author{
Jessica Mancilla-de-la-Cruz \\ Research Assistant, jessica.mancruz@gmail.com \\ Marisela Rodriguez-Salvador \\ Full Professor, marisrod@tec.mx
}

Tecnologico de Monterrey, Av. Eugenio Garza Sada 2501, Col. Tecnológico, Monterrey, N.L. C.P. 64849, México

\section{Laura Ruiz-Cantu}

Transitional Assistant Professor, Centre for Additive Manufacturing, Faculty of Engineering, Laura.Ruiz@nottingham.ac.uk

University of Nottingham, Nottingham NG7 2RD, United Kingdom

\begin{abstract}
A dditive manufacturing (AM) is increasingly gaining a presence in the pharmaceutical industry, specifically in the reconfiguration of drug delivery systems wherein new products are being developed for administering pharmaceuticals inside the body, and drug testing systems wherein complex tissues are created to analyze medical treatments. This paper proposes a novel methodology of Competitive Technology Intelligence (CTI) to uncover the evolution of new drug delivery products where additive manufacturing is present. Using the multiple linear regression analysis and hype cycle model as a conceptual basis, we processed data from scientific papers and patents

indexed by Scopus and PatSnap for the period of 2004-2019. The outcomes of this study can create a relevant knowledge base for decision-making on introducing novel technologies such as AM. Industrial and academic communities are devoting important efforts toward the advancement of $\mathrm{AM}$ in the health industry, especially pharmaceuticals. It is expected that this technology will bring new solutions to address fundamental global health problems. However, this technology is still in its very early stage. Therefore, investments should focus on research and development (R\&D) to build a solid foundation for commercialization in the next decade.
\end{abstract}

\section{Keywords:}

competitive technology intelligence; additive manufacturing; patent analysis; hype cycle; 3D printing; pharmacy; targeted drug delivery; new treatments

Citation: Mancilla-de-la-Cruz J., Rodriguez-Salvador M., Ruiz-Cantu L. (2020) The Next Pharmaceutical Path: Determining Technology Evolution in Drug Delivery Products Fabricated with Additive Manufacturing. Foresight and STI Governance, vol. 14, no 3, pp. 55-70. DOI: 10.17323/2500-2597.2020.3.55.70 
A dditive Manufacturing (AM), also known as 3D printing, rapid prototyping, and solid freeform fabrication, is a relatively new manufacturing method. Globally, AM and 3D printing are the most widely known terms. In 2015, the American Society for Testing and Materials (ASTM) defined AM as the "process of joining materials to make parts from 3D model data, usually layer upon layer, as opposed to subtractive manufacturing and formative manufacturing methodologies." ${ }^{1}$ While $3 \mathrm{D}$ printing is defined by the ASTM as the "fabrication of objects through the deposition of a material using a print head, nozzle, or another printer technology" this term is often used in a non-technical context synonymously with AM. In order to solidify the materials, AM also uses a source of energy such as a laser, a binder, or an electron beam [Ching-Chiang, Yi-Fan, 2018]. According to the ASTM, $\mathrm{AM}$ is divided into seven principal categories: binder jetting, direct energy deposition, material extrusion, material jetting, powder bed fusion, sheet lamination, and vat photopolymerization. Each of these designations exhibit singular characteristics.

AM can contribute to the development and change of traditional pharmaceutical manufacturing due to its unique advantages such as the ability to create complex products, personalization, and on-demand manufacturing [Liam et al., 2018]. Spritam (Aprecia Pharmaceuticals, Blue Ash, OH, USA) represents a pioneering example. Spritam is a drug that was produced using AM and was approved in August 2015 by the US Food and Drug Administration (FDA) [Groll et al., 2018; Jamroz et al., 2018].

According to a report by the U.S. Department of Health and Human Services and the U.S. Food and Drug Administration (FDA) in the next few years, we will see an evolution in medicine towards tailored medicine also known as precision medicine [Hamburg, 2013]. Personalized medicine is a field in healthcare that aims to personalize preventive and therapeutic strategies to the unique physiology, biochemistry, lifestyles, and genetics of individual patients [Sadée, Dai, 2005]. The evolution towards precision medicine is being driven by scientific and technological advances in complex fields from genomics to artificial intelligence as a consequence of the huge variability of people's reactions to drugs [Evans, Relling, 2004]. Demand for superior products related to drug delivery has been growing in the last few years and it is expected that personalized medication will bring enormous benefits transforming the health sector [Jamroz et al., 2018].

While studies on the characteristics, applications, and processes of AM for the pharmaceutical industry exist, analyses to determine the dynamics of the scientific and technological output have been scarce particularly for drug delivery. In addition, due to the novelty of the field, the AM domain is constantly changing even in terms of its root conception. This study contributes to the advancement of research on AM for pharma- ceutical applications, specifically filling the gap related to the lack of studies on the dynamics of scientific and technological production for Drug Delivery Systems (DDSs). To accomplish this goal, Competitive and Technology Intelligence (CTI) was utilized. CTI is a methodology that consists of gathering, analyzing, and transforming scientific and technological information to create relevant knowledge that contributes to the decision making of an organization [Colakogly, 2011; Rodriguez et al., 2019]. Our CTI approach integrates 1) a hype cycle model to identify drug delivery products fabricated with AM and their development stage, and to broaden this scope, 2) a multiple linear regression was executed to determine the principal technology areas of medical inventions made by AM. Scientific and technological information was analyzed up to October 2019, when the collecting activity was concluded.

\section{Background}

\section{Drug Delivery Systems}

Drug Delivery Systems (DDSs) are focused on the controlled release of active pharmaceutical ingredients (APIs) in the human body. In order to develop DDSs, pharmaceutical engineering processes have been modified over the years pursuing both the highest performance to heal the patient and efficacy. Currently, the goal is to produce the most efficient administration of drugs. In this context, processes to enable drug transport into the circulatory system have been developed favoring drug movement across cells and tissues. Many new methods of drug administration have been formulated, varying from implantable devices using permeable membranes to injectable microspheres [Rajgor et al., 2011; Wang et al., 2017]. Also, DDS is carried out through nine different routes of drug administration: oral, topical, rectal, vaginal, parenteral, intradermal, inhaled, ophthalmic, and otic [Liam et al., 2018].

AM has unique advantages for pharmaceutical applications, in fact, it is expected that this technology will revolutionize the development of new drugs and their delivery methods [Jamroz et al., 2018, Goole, Amighi, 2016], specifically in terms of:

- Personalized medicine: AM provides the opportunity to customize the medication, by printing small batches of drugs [Liam et al., 2018; Goyanes et al., 2017; Palo et al., 2017; Trenfield et al., 2018] according to each patient characteristic: genetic profile, metabolic activity, and disease severity.

- Drug release: the flexibility to print medicine in a variety of doses and geometries, obtaining different dimensions, designs, and levels of porosities. Such are important characteristics that can alter the release of drugs in the body [Goyanes et al., 2017; Palo et al., 2017; Sadia et al., 2016; Trenfield et al., 2018]. 
- Multiple Active Pharmaceutical Ingredients: personalized products that contain multiple APIs according to specific patient requirements. An example of this product are the tablets known as polypills. The benefits of this combinatorial approach are significant, the primary being a reduction of the medical burden associated with a multitude of different medications for the elderly [Liam et al., 2018; Palo et al., 2017; Trenfield et al., 2018].

Moreover, AM not only could facilitate the fabrication process by providing the possibility of carrying a specific drug dosage, but also allows controlling the speed of the drug release and its arrival to a specific location in the body, ${ }^{2}$ being so attractive to improve efficiency for drug delivery purposes.

\section{Hype Cycle Model}

The hype cycle model enables researchers to understand the expectations for and maturity that a technology could have. It supports the R\&D decision-making process considering costs and benefits connected with the adoption of a specific technology from its early stage to a superior stage of maturity [Dedehayir, Steinet, 2016; Gartner Research, 2018]. This model was created in 1995 for Gartner Group, a global research and advisory firm that provides information on how technologies may impact the organization and how to adapt to them and gain competitive advantages [Gartner Research, 2018; O'Leary, 2008]. The hype cycle model is represented in a bi-dimensional graph where the expectation or visibility measure of the technology is the "Y" axis and time is the " $\mathrm{X}$ " axis. This is divided into five phases: innovation trigger, peak of inflated expectations, trough of disillusionment, slope of enlightenment, and the plateau of productivity [Dedehayir, Steinet, 2016; Gartner Research, 2018; Lente et al., 2013; O'Leary, 2008; White, Samuel, 2019] which are described as follows.

- Innovation trigger phase: this phase includes the beginning of new technologies, those with proof of concepts where the basic design research is conducted [Dedehayir, Steinert, 2016; O'Leary, 2008]. Also, venture investments take place with the hope of obtaining a highly competitive advantage by being the pioneers [Dedehayir, Steinert, 2016; Gartner Research, 2018; White, Samuel, 2019]. In this phase, initial media coverage could be high and generate significant publicity [Dedehayir, Steinert, 2016; Gartner Research, 2018; White, Samuel, 2019].

- Peak of inflated expectation phase: there is still limited information about the technology and how it can be applied [O'Leary, 2008]. The main characteristic of this phase is the optimism and exagger- ated expectation that the media produces on the success stories [Dedehayir, Steinert, 2016; Gartner Research, 2018; White, Samuel, 2019]. Business investment and its participation lack a clear strategy and commercial viability [Dedehayir, Steinert, 2016; White, Samuel, 2019].

- Trough of disillusionment phase: this occurs when the technology fails in commercial adoption because the overinflated expectations are difficult to meet, so the company offering the technology needs to readjust expectations and meet performance goals [Dedehayir, Steinert, 2016; Gartner Research, 2018; O'Leary, 2008]. The interest of the media in this phase decreases due to the defective applications and commercial viability of the technology [Dedehayir, Steinert, 2016; White, Samuel, 2019].

- Slope of enlightenment phase: this takes place when the technology achieves more robustness and has grown both in its application and understanding [Dedehayir, Steinert, 2016; Gartner Research, 2018; O'Leary, 2008; White, Samuel, 2019].

- Plateau of productivity phase: this represents the beginning of the mainstream adoption of the technology [Dedehayir, Steinert, 2016; Gartner Research, 2018]. The technology expands its applicability and relevance on the market by presenting greater commercial viability [Dedehayir, Steinert, 2016; Gartner Research, 2018; White, Samuel, 2019]. Risk decreases and organizations feel more comfortable with the adoption of the technology [O'Leary, 2008].

In addition, the hype cycle model can show the different growth rates adopted by the technologies while undergoing the hype cycle, considering that each technology has unique characteristics that determine its evolution. In this respect, the hype cycle shows five periods: 1) less than two years, 2) two to five years, 3 ) five to ten years, 4) more than 10 years, and 5) obsolete before plateau [Gartner Research, 2018].

\section{Multiple Linear Regression}

The Multiple Linear Regression technique involves the observation of two or more points over time for the same case or individual. Of the different techniques that exist, multiple linear regression analysis was chosen as a complement to the hype cycle analysis as it facilitates the study of the relationship between two or more dependent variables and an independent variable over time. ${ }^{3}$ For the purpose of this research, multiple linear regression was applied with the objective of determining the principal trends of patent activity through the analysis of International Patent Codes

\footnotetext{
${ }^{1}$ Available at: https://www.iso.org/obp/ui/\#iso:std:iso-astm:52900:ed-1:v1:en, accessed 08.10.2019.

Available at: https://www.nibib.nih.gov/science-education/science-topics/drug-delivery-systems, accessed 25.10.2019.

3 Available at: https://data-flair.training/blogs/r-linear-regression-tutorial/, accessed 14.05.2020.
} 
(IPCs), as they represent the technology domain that each patent has under a standardized and well-known classification. Multiple linear regression analysis provides the opportunity to identify the independent variable most significant for the dependent variable, by using the following equation:

$Y_{\mathrm{t}}=\beta_{0}+\beta_{1} x_{1 t}+\beta_{2} x_{2 t}+\ldots+\beta_{p} x_{p t}+\varepsilon_{t^{\prime}}(1)$

Where $\mathrm{Y}$ is the dependent variable and $\beta_{0}$ is the point at which the regression plane intercepts the $y$-axis. $x$ 's are the independent variables and $\beta$ is its slope, the unknown regression coefficient. While $t$ represents the time of observation and $\varepsilon$ is the residual error of each observation. ${ }^{4}$ In this study $(\mathrm{Y})$ was examined as the total number of patents published by year with the specific IPC B33Y80/00 since it corresponds to the category of Products Made for Additive Manufacturing while the independent variables (x's) focused on the predominant 99 IPCs from the patent dataset previously determined. In a further stage, the IPCs that belong to the Medical Science category were studied as independent variables.

\section{Methodology}

\section{First Stage. Determination of the Search Strategy}

In order to collect the right scientific and technological information, it is important to create a proper search query with elements that define the domain of study properly. This research was driven by scientific documents and patents gathering, in which it was observed that the terminology related to AM is highly complex and is evolving constantly. As a consequence, a first identification of the International Patent Code (IPC) and of the most suitable terminology (keywords) was made.

IPC consists of an international hierarchical system applied in the patent record. This study considered the IPC B33Y80/00 that refers to "Products Made by Additive Manufacturing". With regard to the terminology, specific keywords were established through a deep analysis combining primary and secondary information sources: expert opinions and scientific publications from the Scopus database. In particular, consultations with $\mathrm{AM}$ and $3 \mathrm{D}$ printing specialists for pharmaceutical applications from The University of Nottingham were undertaken. For this study, two groups of keywords were built, one for AM and one for DDSs, Table 1 shows the obtained results.

\section{Second Stage. Scientific and Technological Document Gathering}

This involves information collection to generate different datasets. Scientific papers and patents were analyzed during this study. The first ones were used because they are documents that show the progress of research and are indexed by prestigious platforms such as Scopus. Meanwhile patents were considered as they reflect the advances of technological inventions backed by a government entity that grants rights and exclusivity.

This study considered both Scopus ${ }^{5}$ and PatSnap ${ }^{6}$ as reliable sources to show the progress of research and development. Scopus was used to retrieve scientific literature. This platform covers more than 20,000 scientific journals, 370 books, and 5.5 million conference proceedings. It contains a variety of information including citations since 1996 and library document summaries. Moreover, Scopus provides strong tools to analyze and graph worldwide research. ${ }^{7}$

To gather patents, the platform PatSnap was utilized because it is a powerful tool that has access to a database of more than 130 million patents across 128 jurisdictions. ${ }^{8}$

For both kinds of documents (papers and patents) the strategy search comprised the entire database coverage of Scopus and PatSnap until October 31, 2019, which corresponds with the end date of the collection period. For this study, three datasets were created as it can be seen in Table 2:

- The first dataset was built for the hype cycle analysis and it is comprised of scientific papers from Scopus describing drug delivery products made by AM. Keywords from Table 1 were used to generate the search query and collect documents.

- The second dataset was made for hype cycle analysis as well, but the type of documents is different, in this case, it included patents from the PatSnap platform presenting drug delivery products made by AM. For this task, the search query encompasses the IPC B33Y80/00 (Products Made by Additive Manufacturing) and keywords from Table 1.

- The third dataset was created for the multiple linear regression analysis in order to collect all patents related to products created by means of additive manufacturing, toward this end the PatSnap platform was utilized with a search query focused

\footnotetext{
${ }_{4}^{4}$ Available at: https://www.sciencedirect.com/topics/medicine-and-dentistry/multiple-linear-regression-analysis, accessed 14.05.2020.

Available at: https://www.elsevier.com/es- mx/solutions/scopus, accessed 12.11.2019.

${ }^{6}$ Available at: https://www.patsnap.com, accessed 22.11.2019.

Available at: https://service.elsevier.com/app/answers/detail/a_id/15534/c/10543/supporthu b/scopus/, accessed 22.11.2019.

${ }_{8}^{8}$ Available at: https://help.patsnap.com/hc/en-us/articles/360000299757-Search-And-Boolean-101, accessed 22.11.2019.
} 


\section{Table 1. Terminology for Additive Manufacturing and Drug Delivery Systems}

\begin{tabular}{|c|c|c|}
\hline \multicolumn{2}{|r|}{ Group } & Keywords \\
\hline \multicolumn{2}{|r|}{$\mathrm{AM}$} & $\begin{array}{l}\text { 3D printing, additive manufacturing, freeform fabrication, desktop fabrication, solid freeform fabrication, } \\
\text { binder jetting, material extrusion, direct energy deposition, material jetting, powder bed fusion, sheet } \\
\text { lamination, vat photopolymerization, fused deposition modeling, fused filament fabrication, pressure-assisted } \\
\text { microsyringe, semisolid extrusion, semi-solid extrusion, extrusion freeform fabrication, extrusion base } \\
\text { freeform, pneumatic extrusion, mechanical extrusion, screw extrusion, syringe extrusion, drop on demand, } \\
\text { drop on drop, drop on solid, drop on powder, selective laser sintering, selective laser melting, stereolithography, } \\
\text { digital light processing, } 2 \text { photon polymerization, continuous liquid interface production, continuous inkjet } \\
\text { printing. }\end{array}$ \\
\hline \multirow[t]{3}{*}{ DDSs } & $\begin{array}{l}\text { Vaginal and } \\
\text { rectal }\end{array}$ & $\begin{array}{l}\text { Vaginal or rectal drug administration, vaginal or rectal dosage, vaginal or rectal dosage form, vaginal or } \\
\text { rectal screening form, vaginal or rectal release controlled, vaginal or rectal drug release, vaginal or rectal drug } \\
\text { delivery, suppository, vaginal suppository, DIU, IUD, intrauterine device, intrauterine contraceptive device. }\end{array}$ \\
\hline & Topical & $\begin{array}{l}\text { Topical drug administration, topical dosage, topical dosage form, topical screening form, topical release } \\
\text { controlled, topical drug release, topical drug delivery, facemask, wound dressing. }\end{array}$ \\
\hline & Intradermal & $\begin{array}{l}\text { Intradermal drug administration, intradermal dosage, intradermal dosage form, intradermal screening form, } \\
\text { intradermal release controlled, intradermal drug release, intradermal drug delivery, microneedle. }\end{array}$ \\
\hline
\end{tabular}

on the specific IPC B33Y80/00 (Products Made by Additive Manufacturing). Further in a later section, the IPCs that comprise the Medical Science category were analyzed as the fourth stage exhibits.

In addition for the first two datasets, after the collecting activity, a data cleaning process was executed to identify incorrect or incomplete data, data not aligned with the study core, or papers that by themselves do not represent specific research as paper reviews. The third dataset did not require this process since the search was driven by the specifically the IPC B33Y80/00 (Products Made by Additive manufacturing) code, which belongs precisely to the domain under analysis for this study.

Since organizations frequently protect a patent in several patent offices, to avoid patent duplication the information obtained for the second and third datasets was filtered by a simple patent family (SPF), meaning that only the first patent application was examined. Knowledge of the case study and expert feedback were relevant in order to collect proper information for all the datasets. Table 2 shows the results obtained for each dataset.

\section{Third Stage. Hype Cycle Analysis}

The third stage starts with the identification of the specific components where the hype cycle will be applied, in this case, the different routes of drug administration for products fabricated with AM. As in the previous stages, the knowledge of the subject, revision of documents gathered, and advice from experts, particularly from The University of Nottingham, added a great amount of value. In total, five routes of drug delivery were identified where AM was applied, which include oral, vaginal, rectal, topical, and intradermal. Specific products belonging to each group were then determined. Table 3 shows the main outcomes.

After that, this stage continues with the identification of the bibliometric indicators and the evaluation criteria that determine each phase of the hype cycle. The hype cycle model has five phases listed above: Innovation trigger, Peak of inflated expectation, Trough of disillusionment, Slope of enlightenment, and Plateau of productivity. The cycle demonstrates that technologies evolve at different paces. In order to uncover the specific stage of technological development, this research established an additional division (stages) for all the hype cycle phases except the last one where technology is consolidated (applications are at a superior level and the commercial viability is already demonstrated). For this aim, the principles of Gartner [Gartner Research, 2018], the research of O'Leary, entitled “Gartner's hype cycle and information system research issue" [O'Leary, 2008] were considered.

Table 2. Main Characteristics of the Created Datasets

\begin{tabular}{|c|c|c|c|c|c|}
\hline Dataset & $\begin{array}{c}\text { Source of } \\
\text { Information }\end{array}$ & $\begin{array}{l}\text { Search query based } \\
\text { upon }\end{array}$ & $\begin{array}{c}\text { Number of } \\
\text { documents } \\
\text { obtained }\end{array}$ & Type of documents & Analysis to be applied \\
\hline 1 & Scopus & Keywords & 253 & Scientific papers & \multirow{2}{*}{ Hype cycle } \\
\hline 2 & \multirow{2}{*}{ PatSnap } & IPC and Keywords & 81 & \multirow{2}{*}{ Simple Patent Families } & \\
\hline 3 & & IPC & 5847 & & $\begin{array}{l}\text { Multiple linear } \\
\text { regression }\end{array}$ \\
\hline
\end{tabular}


Table 3. Identification of Drug Delivery Products Fabricated with Additive Manufacturing

\begin{tabular}{|c|c|c|c|}
\hline Dataset & $\begin{array}{c}\text { Route of } \\
\text { administration }\end{array}$ & Dosage form & $\begin{array}{l}\text { Number of } \\
\text { documents }\end{array}$ \\
\hline \multirow{9}{*}{$\begin{array}{l}\text { 1. Scientific } \\
\text { Papers }\end{array}$} & \multirow{3}{*}{ Oral } & Tablet & 129 \\
\hline & & Capsules & 15 \\
\hline & & Oral film & 23 \\
\hline & \multirow{3}{*}{$\begin{array}{l}\text { Vaginal and } \\
\text { rectal }\end{array}$} & $\begin{array}{c}\mathrm{T} \text { intrauterine } \\
\text { device }\end{array}$ & 5 \\
\hline & & $\begin{array}{l}\text { Suppository } \\
\text { molds }\end{array}$ & 2 \\
\hline & & Vaginal ring & 1 \\
\hline & \multirow{2}{*}{ Topical } & $\begin{array}{l}\text { Wound } \\
\text { dressing }\end{array}$ & 31 \\
\hline & & Facemask & 5 \\
\hline & Intradermal & Microneedle & 42 \\
\hline \multirow{9}{*}{$\begin{array}{l}\text { 2. Simple } \\
\text { Patent } \\
\text { Family }\end{array}$} & \multirow{3}{*}{ Oral } & Tablet & 41 \\
\hline & & Capsules & 13 \\
\hline & & Oral film & 0 \\
\hline & \multirow{3}{*}{$\begin{array}{l}\text { Vaginal and } \\
\text { rectal }\end{array}$} & $\begin{array}{c}\mathrm{T} \text { intrauterine } \\
\text { device }\end{array}$ & 1 \\
\hline & & $\begin{array}{l}\text { Suppository } \\
\text { molds }\end{array}$ & 0 \\
\hline & & Vaginal ring & 2 \\
\hline & \multirow[t]{2}{*}{ Topical } & $\begin{array}{l}\text { Wound } \\
\text { dressing }\end{array}$ & 9 \\
\hline & & Facemask & 0 \\
\hline & Intradermal & Microneedle & 15 \\
\hline
\end{tabular}

After determining all stages, the bibliometric indicators and their evaluation criteria were established. Citations of the papers retrieved from Scopus were considered due to the fact that mass media sources that emerged since the citations represent the dissemination of the ideas expressed by the authors in other scientific papers. The "market attractiveness", "market coverage", and "technology quality" patent scores from PatSnap software were used as indicators of technological performance and market appeal. This platform evaluates these indicators on a scale of 0 to 100 , where the "market attractiveness" score assesses the relevance of a patent on the market. The "market coverage" factor evaluates the market presence of a patent. While the "technology quality" indicator shows the degree of innovation according to the significance of the patented feature to the product. ${ }^{9}$ Hype cycle phase determination and its evaluation criteria are exhibited in Table 4. Once this phase description has been completed, it is important to apply both indicators: number of citations per year for each scientific paper and the "market attractiveness", "market coverage", and "technology quality" scores for each family patent. In this study, citations were determined using Scopus tools in the first dataset and, for patent scores, the PatSnap software was applied in the second dataset.

\section{Fourth Stage. Multiple Linear Regression Analysis}

This stage comprises the evaluation of the third dataset through multiple linear regression analysis of IPCs with the purpose of determining the technology trends in patents. This is where the identification of the principal technology areas of patents can lead to the visualization of trends that impact future product development, namely the products made by additive manufacturing.

For this task, specific IPCs as well as dependent and independent variables should be established. In particular, this analysis focused on collecting patents indexed with the IPC B33Y80/00 Products Made by Additive Manufacturing code whose publication year ranged from 2004 to October 31, 2019 (when collecting activity was concluded). As a result, information about 8,603 patents was obtained. After applying a SPF filter, the dataset was reduced to 5,847 SPFs, which registered more than 1,000 types of IPCs in addition to the IPC B33Y80/00 Products Made by Additive Manufacturing, since each patent can be indexed in databases with more than one IPC. For the purpose of this study, the top 99 IPCs (those most predominant in the SPF) from the more than 1,000 types of IPCs registered were considered for multiple linear regression analysis. The dependent variable $(\mathrm{Y})$ was the total number of patents published by year with the IPC B33Y80/00, while the independent variables (X's) centered on the top 99 IPCs (Table 5)

The execution of the previous equation was performed in the software $\mathrm{R}$ and the results showed that only 10 IPCs were found to be significant for the dependent variable. Six of these IPCs had a positive impact upon the equation, which were: B33Y10/00 Processes of additive manufacturing; B33Y70/00 Materials specially adapted for additive manufacturing; B33Y30/00 Apparatus for additive manufacturing, details thereof or accessories therefor; B33Y50/02 Controlling or regulating additive manufacturing processes; B33Y40/00 Auxiliary operations or equipment, e.g. for material handling; and G06T17/00 3D Modelling for computer graphics (see Box 1).

However, the obtained results showed that there were no IPCs directly related to DDSs fabricated with AM because this is a relatively new field and patents are not public until after two years of being filed. This behavior can also be observed in the hype cycle analysis, where the number of patents indicating presence of additive manufacturing in drug delivery products is small, as can be seen in results for the second dataset shown in Table 3.

In order to complement the hype cycle analysis, a second multiple linear regression analysis was performed having as a dependent variable $(\mathrm{Y})$ : the total number of patents published by year with the IPC B33Y80/00 code, and as independent variables (X's): the IPCs 
from the top 99 IPCs previously obtained but only selecting those that belong to the Medical Science category. Due to the novelty of drug delivery products made with additive manufacturing, there is not a specific classification for them so far. Products related to pharmaceutical and drug delivery are included in the Medical Science category. ${ }^{10}$ Results conveyed that only 28 IPCs of the top 99 IPCs belong to the Medical Science category. The six most predominant in SPF are: A61L27/56 Porous or cellular materials, A61L27/50 Materials characterized by their function or physical properties, A61L27/54 Biologically active materials, e.g. therapeutic substances, A61F2/28 Artificial substitutes or replacements for parts of the bone, A61C13/00 Dental prostheses, A61L27/18 Materials obtained otherwise than by reactions only involving carbonto-carbon (Table 6). Interestingly, as the industry related to medical science is growing so fast, this study's outcomes indicated that the IPC A61L27/56 Porous or cellular materials and IPC A61L27/54 Biologically active materials, e.g. therapeutic substances contributed positively and significantly to the IPC B33Y80/00 Products Made by Additive Manufacturing (see Box 2). These two IPCs were identified as the drivers of the patent technological trends related to products fabricated with AM in the global category of medical science.

\section{Results and Discussion}

During the development of this study, the following insights were obtained. Firstly, it was observed that the terminology related to AM is highly complex and evolving constantly. As a consequence, the keywords used for the design of the information search strategy was so extensive, in some cases, it was difficult to classify, whereas terms associated with pharmaceutical

\section{Table 4. Hype Cycle Phases and its Evaluation Criteria}

\begin{tabular}{|c|c|c|c|c|}
\hline $\begin{array}{l}\text { Hype Cycle } \\
\text { Phase }\end{array}$ & Bibliometric Indicator & Evaluation criteria & Stage & Stage Description \\
\hline \multirow{2}{*}{$\begin{array}{l}\text { Innovation } \\
\text { Trigger }\end{array}$} & \begin{tabular}{|c|} 
Not enough \\
information to evaluate \\
with bibliometric \\
indicators.
\end{tabular} & $\mathrm{N} / \mathrm{A}$ & 1 & $\begin{array}{l}\text { Beginning of the technology, proof of concepts } \\
\text { where foundations to begin research are established. }\end{array}$ \\
\hline & $\begin{array}{l}\text { Number of Scientific } \\
\text { Papers }\end{array}$ & $\begin{array}{l}\text { Number of papers } \\
\text { published }>\text { zero }\end{array}$ & 2 & $\begin{array}{l}\text { Venture investment takes place. Attention from the } \\
\text { media is frequently high and generates significant } \\
\text { publicity. }\end{array}$ \\
\hline \multirow[b]{2}{*}{$\begin{array}{l}\text { Peak of Inflated } \\
\text { Expectations }\end{array}$} & Number of Citations & $\begin{array}{l}\text { An increase in the number } \\
\text { of citations }\end{array}$ & 3 & $\begin{array}{l}\text { Media usually produces exaggerated optimism and } \\
\text { expectations to get success stories. }\end{array}$ \\
\hline & Score Value of Patents & $\begin{array}{l}29 \geq \text { Average (Technology } \\
\text { quality score and Market } \\
\text { coverage score) } \geq 0\end{array}$ & 4 & $\begin{array}{l}\text { Detailed information on the technology and how it } \\
\text { can be applied is scarce. Usually, a clear strategy is } \\
\text { missing and commercial viability is not clear. }\end{array}$ \\
\hline \multirow{2}{*}{\begin{tabular}{c|} 
Trough of \\
Disillusionment
\end{tabular}} & Number of Citations & $\begin{array}{l}\text { A decrease in the number of } \\
\text { citations }\end{array}$ & 5 & $\begin{array}{l}\text { Media publicity decreases due to failures and other } \\
\text { technical issues including commercial viability. }\end{array}$ \\
\hline & $\begin{array}{l}\text { Number of Scientific } \\
\text { Papers }\end{array}$ & $\begin{array}{l}\text { A decrease in the number of } \\
\text { papers published }\end{array}$ & 6 & $\begin{array}{l}\text { Technological commercial adoption may fail since } \\
\text { there were overinflated expectations that were } \\
\text { difficult to meet. Technology needs to set new } \\
\text { expectations to establish real performance. }\end{array}$ \\
\hline \multirow{2}{*}{$\begin{array}{l}\text { Slope of } \\
\text { Enlightenment }\end{array}$} & Score value of Patents & $\begin{array}{c}59 \geq \text { Average (Technology } \\
\text { quality score and Market } \\
\text { coverage score) } \geq 30 \\
29 \geq \text { Average (Market } \\
\text { attractiveness score) } \geq 0\end{array}$ & 7 & $\begin{array}{l}\text { Technology is solid with growing applications and } \\
\text { better understanding. }\end{array}$ \\
\hline & Score value of Patents & $\begin{array}{c}100 \geq \text { Average (Technology } \\
\text { quality score and Market } \\
\text { coverage score) } \geq 60 \\
59 \geq \text { Average (Market } \\
\text { attractiveness score) } \geq 30\end{array}$ & 8 & $\begin{array}{l}\text { The benefits of the technology are clear and have } \\
\text { grounded objectives. The commercial appeal of the } \\
\text { technology increases. }\end{array}$ \\
\hline $\begin{array}{l}\text { Plateau of } \\
\text { Productivity }\end{array}$ & Score value of Patents & $\begin{array}{c}100 \geq \text { Average (Technology } \\
\text { quality score and Market } \\
\text { coverage) } \geq 60 \\
100 \geq \text { Average (Market } \\
\text { attractiveness score) } \geq 60\end{array}$ & 9 & $\begin{array}{l}\text { The technology expands its applicability and } \\
\text { relevance on the market thus gaining greater } \\
\text { commercial viability. }\end{array}$ \\
\hline
\end{tabular}

\footnotetext{
${ }^{10}$ The category comprises a vast range of IPCs that are related to diagnostic-surgery, dentistry, veterinary instruments, prosthesis, transport for patients, physical therapy apparatus, device or methods for bringing pharmaceutical products, containers specially adapted for medical or pharmaceutical purposes, devices for administering food or medicines orally, materials for bandages/dressing, methods or apparatus for sterilizing materials, and devices for introducing media into or onto the body.
} 
Table 5. Independent Variables

\begin{tabular}{|c|l|c|}
\hline $\begin{array}{c}\text { Independent } \\
\text { variables }\end{array}$ & \multicolumn{1}{|c|}{ IPC } & $\begin{array}{c}\text { Number } \\
\text { of SPF }\end{array}$ \\
\hline $\mathrm{X} 1$ & $\mathrm{~B} 33 \mathrm{Y} 10 / 00$ & 3272 \\
\hline $\mathrm{X} 2$ & $\mathrm{~B} 33 \mathrm{Y} 70 / 00$ & 1328 \\
\hline $\mathrm{X} 3$ & $\mathrm{~B} 22 \mathrm{~F} 3 / 105$ & 982 \\
\hline $\mathrm{X} 4$ & $\mathrm{~B} 29 \mathrm{C} 67 / 00$ & 855 \\
\hline $\mathrm{X} 5$ & $\mathrm{~B} 33 \mathrm{Y} 30 / 00$ & 812 \\
\hline $\mathrm{X} 6$ & $\mathrm{~B} 33 \mathrm{Y} 50 / 02$ & 552 \\
\hline $\mathrm{X} 7$ & $\mathrm{~B} 33 \mathrm{Y} 50 / 00$ & 427 \\
\hline $\mathrm{X} 8$ & $\mathrm{~B} 33 \mathrm{Y} 40 / 00$ & 320 \\
\hline $\mathrm{X} 9$ & $\mathrm{~B} 28 \mathrm{~B} 1 / 00$ & 238 \\
\hline $\mathrm{X} 10$ & $\mathrm{~B} 23 \mathrm{~K} 26 / 342$ & 230 \\
\hline $\mathrm{X} 11$ & $\mathrm{~B} 29 \mathrm{C} 64 / 106$ & 230 \\
\hline $\mathrm{X} 12$ & $\mathrm{~B} 22 \mathrm{~F} 5 / 00$ & 219 \\
\hline $\mathrm{X} 13$ & $\mathrm{~B} 29 \mathrm{C} 64 / 386$ & 218 \\
\hline $\mathrm{X} 14$ & $\mathrm{~B} 29 \mathrm{C} 64 / 118$ & 214 \\
\hline $\mathrm{X} 15$ & $\mathrm{~B} 29 \mathrm{C} 64 / 153$ & 213 \\
\hline $\mathrm{X} 16$ & $\mathrm{~B} 29 \mathrm{C} 64 / 112$ & 182 \\
\hline $\mathrm{X} 17$ & $\mathrm{~B} 22 \mathrm{~F} 3 / 24$ & 170 \\
\hline $\mathrm{X} 18$ & $\mathrm{~B} 22 \mathrm{~F} 3 / 16$ & 156 \\
\hline $\mathrm{X} 19$ & $\mathrm{~A} 61 \mathrm{~L} 27 / 56$ & 155 \\
\hline $\mathrm{X} 20$ & $\mathrm{~B} 29 \mathrm{C} 33 / 38$ & 152 \\
\hline $\mathrm{X} 21$ & $\mathrm{~B} 29 \mathrm{C} 64 / 165$ & 145 \\
\hline $\mathrm{X} 22$ & $\mathrm{~B} 29 \mathrm{C} 64 / 10$ & 144 \\
\hline $\mathrm{X} 23$ & $\mathrm{~B} 22 \mathrm{~F} 5 / 10$ & 143 \\
\hline $\mathrm{X} 24$ & $\mathrm{~B} 29 \mathrm{C} 64 / 393$ & 141 \\
\hline $\mathrm{X} 25$ & $\mathrm{~A} 61 \mathrm{~L} 27 / 50$ & 140 \\
\hline $\mathrm{X} 26$ & $\mathrm{~B} 29 \mathrm{~L} 31 / 00$ & 140 \\
\hline $\mathrm{X} 27$ & $\mathrm{~A} 61 \mathrm{~L} 27 / 54$ & 121 \\
\hline $\mathrm{X} 28$ & $\mathrm{~B} 22 \mathrm{~F} 1 / 00$ & 117 \\
\hline $\mathrm{X} 29$ & $\mathrm{~B} 23 \mathrm{~K} 15 / 00$ & 109 \\
\hline $\mathrm{X} 30$ & $\mathrm{~B} 29 \mathrm{C} 64 / 40$ & 109 \\
\hline $\mathrm{X} 31$ & $\mathrm{~A} 61 \mathrm{~F} 2 / 28$ & 108 \\
\hline $\mathrm{X} 32$ & $\mathrm{~B} 22 \mathrm{~F} 3 / 00$ & 107 \\
\hline $\mathrm{X} 33$ & $\mathrm{G} 06 \mathrm{~F} 17 / 50$ & 103 \\
\hline & & \\
\hline
\end{tabular}

\begin{tabular}{|c|l|c|}
\hline $\begin{array}{c}\text { Independent } \\
\text { variables }\end{array}$ & \multicolumn{1}{|c|}{ IPC } & $\begin{array}{c}\text { Number } \\
\text { of SPF }\end{array}$ \\
\hline $\mathrm{X} 34$ & $\mathrm{~A} 61 \mathrm{C} 13 / 00$ & 102 \\
\hline $\mathrm{X} 35$ & $\mathrm{~A} 61 \mathrm{~L} 27 / 18$ & 102 \\
\hline $\mathrm{X} 36$ & $\mathrm{~B} 22 \mathrm{~F} 5 / 04$ & 102 \\
\hline $\mathrm{X} 37$ & $\mathrm{~A} 61 \mathrm{~F} 2 / 30$ & 101 \\
\hline $\mathrm{X} 38$ & $\mathrm{~A} 61 \mathrm{~B} 34 / 10$ & 99 \\
\hline $\mathrm{X} 39$ & $\mathrm{~B} 29 \mathrm{~K} 105 / 00$ & 96 \\
\hline $\mathrm{X} 40$ & $\mathrm{~B} 29 \mathrm{C} 64 / 00$ & 93 \\
\hline $\mathrm{X} 41$ & $\mathrm{~B} 22 \mathrm{C} 9 / 10$ & 92 \\
\hline $\mathrm{X} 42$ & $\mathrm{~A} 61 \mathrm{~L} 27 / 58$ & 85 \\
\hline $\mathrm{X} 43$ & $\mathrm{~F} 01 \mathrm{D} 5 / 18$ & 85 \\
\hline $\mathrm{X} 44$ & $\mathrm{~B} 29 \mathrm{C} 64 / 20$ & 83 \\
\hline $\mathrm{X} 45$ & $\mathrm{~B} 22 \mathrm{~F} 7 / 08$ & 82 \\
\hline $\mathrm{X} 46$ & $\mathrm{~B} 29 \mathrm{C} 64 / 124$ & 78 \\
\hline $\mathrm{X} 47$ & $\mathrm{G} 05 \mathrm{~B} 19 / 409$ & 78 \\
\hline $\mathrm{X} 48$ & $\mathrm{~A} 61 \mathrm{~L} 27 / 38$ & 75 \\
\hline $\mathrm{X} 49$ & $\mathrm{~B} 22 \mathrm{~F} 7 / 06$ & 75 \\
\hline $\mathrm{X} 50$ & $\mathrm{~B} 22 \mathrm{~F} 3 / 11$ & 74 \\
\hline $\mathrm{X} 51$ & $\mathrm{~A} 61 \mathrm{C} 8 / 00$ & 70 \\
\hline $\mathrm{X} 52$ & $\mathrm{~B} 22 \mathrm{~F} 3 / 10$ & 68 \\
\hline $\mathrm{X} 53$ & $\mathrm{~B} 23 \mathrm{~K} 26 / 00$ & 67 \\
\hline $\mathrm{X} 54$ & $\mathrm{~B} 29 \mathrm{C} 64 / 209$ & 66 \\
\hline $\mathrm{X} 55$ & $\mathrm{~B} 29 \mathrm{D} 11 / 00$ & 62 \\
\hline $\mathrm{X} 56$ & $\mathrm{~F} 01 \mathrm{D} 5 / 28$ & 62 \\
\hline $\mathrm{X} 57$ & $\mathrm{~A} 61 \mathrm{~L} 27 / 12$ & 61 \\
\hline $\mathrm{X} 58$ & $\mathrm{~B} 22 \mathrm{C} 9 / 02$ & 58 \\
\hline $\mathrm{X} 59$ & $\mathrm{~A} 61 \mathrm{~B} 17 / 17$ & 57 \\
\hline $\mathrm{X} 60$ & $\mathrm{C} 04 \mathrm{~B} 35 / 622$ & 57 \\
\hline $\mathrm{X} 61$ & $\mathrm{~A} 61 \mathrm{C} 7 / 00$ & 56 \\
\hline $\mathrm{X} 62$ & $\mathrm{~B} 23 \mathrm{~K} 26 / 70$ & 56 \\
\hline $\mathrm{X} 63$ & $\mathrm{~B} 29 \mathrm{C} 64 / 30$ & 56 \\
\hline $\mathrm{X} 64$ & $\mathrm{~B} 28 \mathrm{~B} 1 / 30$ & 55 \\
\hline $\mathrm{X} 65$ & $\mathrm{~B} 29 \mathrm{C} 64 / 135$ & 54 \\
\hline $\mathrm{X} 66$ & $\mathrm{~F} 01 \mathrm{D} 5 / 14$ & 54 \\
\hline & & \\
\hline
\end{tabular}

\begin{tabular}{|c|l|c|}
\hline $\begin{array}{c}\text { Independent } \\
\text { variables }\end{array}$ & \multicolumn{1}{|c|}{ IPC } & $\begin{array}{c}\text { Number } \\
\text { of SPF }\end{array}$ \\
\hline X67 & B22C9/04 & 51 \\
\hline X68 & B29C64/379 & 50 \\
\hline X69 & A61F2/44 & 49 \\
\hline X70 & G06T17/00 & 48 \\
\hline X71 & A61L27/20 & 47 \\
\hline X72 & A61L27/36 & 46 \\
\hline X73 & F01D9/04 & 45 \\
\hline X74 & A61L27/04 & 43 \\
\hline X75 & B29C35/08 & 43 \\
\hline X76 & A61L27/52 & 42 \\
\hline X77 & B22C7/02 & 42 \\
\hline X78 & A61B5/00 & 41 \\
\hline X79 & B29C45/26 & 41 \\
\hline X80 & A61B17/00 & 40 \\
\hline X81 & A61C9/00 & 40 \\
\hline X82 & A61L27/22 & 40 \\
\hline X83 & A61N5/10 & 40 \\
\hline X84 & B23K101/00 & 40 \\
\hline X85 & B29C64/129 & 40 \\
\hline X86 & G09B23/30 & 40 \\
\hline X87 & A61C7/08 & 39 \\
\hline X88 & A61F5/01 & 38 \\
\hline X89 & A61L31/14 & 38 \\
\hline X90 & B22F7/00 & 38 \\
\hline X91 & B23K26/34 & 38 \\
\hline X92 & C12M3/00 & 38 \\
\hline X93 & C22C14/00 & 38 \\
\hline X94 & A61B90/00 & 37 \\
\hline X95 & B22F3/15 & 37 \\
\hline X96 & B29C64/141 & 37 \\
\hline X97 & C09D11/101 & 37 \\
\hline X98 & F01D25/00 & 37 \\
\hline X99 & F01D25/12 & 37 \\
\hline & & \\
\hline
\end{tabular}

Source: authors.

applications of DDSs presented a more precise definition. Secondly, in this research, drug delivery products fabricated with additive manufacturing and their evolution were identified through the hype cycle analysis of scientific documents and patents. Finally, multiple linear regression analysis was applied to identify the patent trends, however it was found that due to the early stage of this technology, there was not a specific classification for them. Instead, the Medical Science category where AM is used was applied for the identification of IPCs. This was carried out to broaden the scope of the study.

\section{Drug Delivery Products Created with Additive Manufacturing}

The presence of additive manufacturing to produce drug delivery products was disclosed according to the Hype Cycle Gartner model. For this purpose, the evaluation criteria presented in Table 4 were considered. Then, the evolution of drug delivery products was determined, Table 7 illustrates the obtained outcomes.

These results were transformed into a hype cycle graph considering the time range of the development for each type of product as Figure 1 shows.
The results of this research show that DDS is carried out through nine different routes of administration: oral, topical, rectal, vaginal, parenteral, intradermal, inhaled, ophthalmic, and otic. However, for only five of them: oral, topical, rectal, vaginal, and intradermal was evidence found of AM applications to fabricate them. Applying the methodology proposed in this study on these five groups, the following findings were obtained:

- Oral film, suppository, and facemasks are in stage 3 of the Peak of Inflated Expectations phase, where the media usually confer an overblown optimism to the technology. The results show a small number of scientific papers: 23 documents for oral film, two for suppositories, and five for facemasks. However, these papers presented a high number of citations: 495 citations for oral film papers, five citations for suppositories, and 90 citations for facemasks. Patent registration was not detected.

- Tablet, capsule, vaginal ring, wound dressing, and microneedles are products that have reached stage 4, which belong to the Peak of Inflated Expectations phase. During this stage, detailed infor- 


\section{Box 1. First Multiple Linear Regression Analysis}

$Y($ dependent variable $)=$ the total number of patents published by year with the IPC B33Y80/00

X's (independent variables) $=$ the top 99 IPCs (those most predominant in SPF)

Call:

$\operatorname{lm}($ formula $=\mathrm{Y} \sim \mathrm{X} 1+\mathrm{X} 2+\ldots+\mathrm{X} 99$, data $=$ For_R $)$
Residuals:

\begin{tabular}{|l|r|l|r|}
\hline $\mathbf{1}$ & $-5.139 \mathrm{e}-27$ & $\mathbf{9}$ & $9.076 \mathrm{e}-27$ \\
\hline $\mathbf{2}$ & $-2.421 \mathrm{e}-14$ & $\mathbf{1 0}$ & $1.517 \mathrm{e}-27$ \\
\hline $\mathbf{3}$ & $4.483 \mathrm{e}-15$ & $\mathbf{1 1}$ & $-2.057 \mathrm{e}-26$ \\
\hline $\mathbf{4}$ & $1.651 \mathrm{e}-14$ & $\mathbf{1 2}$ & $-8.916 \mathrm{e}-28$ \\
\hline $\mathbf{5}$ & $-2.323 \mathrm{e}-26$ & $\mathbf{1 3}$ & $7.965 \mathrm{e}-28$ \\
\hline $\mathbf{6}$ & $3.906 \mathrm{e}-15$ & $\mathbf{1 4}$ & $-1.128 \mathrm{e}-28$ \\
\hline $\mathbf{7}$ & $-1.596 \mathrm{e}-15$ & $\mathbf{1 5}$ & $-2.674 \mathrm{e}-28$ \\
\hline $\mathbf{8}$ & $-1.044 \mathrm{e}-27$ & $\mathbf{1 6}$ & $1.996 \mathrm{e}-28$ \\
\hline
\end{tabular}

Coefficients (89 not defined because of singularities)

\begin{tabular}{|c|c|c|c|c|}
\hline & Estimate & Std. Error & $\mathrm{t}$ value & $\operatorname{Pr}(>|\mathrm{t}|)$ \\
\hline (Intercept) & $8.527 \mathrm{e}-14$ & $5.470 \mathrm{e}-15$ & $1.559 \mathrm{e}+01$ & $1.97 \mathrm{e}-05^{\star * *}$ \\
\hline $\mathrm{X} 1$ & $1.000 \mathrm{e}+00$ & $1.447 \mathrm{e}-14$ & $6.910 \mathrm{e}+13$ & $<2 \mathrm{e}-16^{* * *}$ \\
\hline $\mathrm{X} 2$ & $1.000 \mathrm{e}+00$ & $1.447 \mathrm{e}-14$ & $6.910 \mathrm{e}+13$ & $<2 \mathrm{e}-16^{* * *}$ \\
\hline $\mathrm{X} 3$ & $-4.120 e+00$ & $6.447 \mathrm{e}-13$ & $-6.107 e+12$ & $<2 \mathrm{e}-16^{* * *}$ \\
\hline $\mathrm{X} 4$ & $-7.492 \mathrm{e}-01$ & $1.618 \mathrm{e}-13$ & $-4.632 e+12$ & $<2 \mathrm{e}-16^{* * *}$ \\
\hline $\mathrm{X} 5$ & $4.869 \mathrm{e}+00$ & $8.243 e-13$ & $5.908 e+12$ & $<2 \mathrm{e}-16^{* * *}$ \\
\hline $\mathrm{X} 6$ & $6.658 \mathrm{e}+00$ & $3.489 \mathrm{e}-13$ & $1.908 \mathrm{e}+13$ & $<2 \mathrm{e}-16^{* * *}$ \\
\hline $\mathrm{X} 7$ & $-3.780 \mathrm{e}-01$ & $8.400 \mathrm{e}-13$ & $-4.500 \mathrm{e}+11$ & $<2 \mathrm{e}-16^{* * *}$ \\
\hline $\mathrm{X} 8$ & $7.492 \mathrm{e}-01$ & $1.556 \mathrm{e}-13$ & $4.814 \mathrm{e}+12$ & $<2 \mathrm{e}-16^{* * *}$ \\
\hline X9 & $-7.656 e+00$ & $8.521 \mathrm{e}-13$ & $-8.984 e+12$ & $<2 \mathrm{e}-16^{* * *}$ \\
\hline $\mathrm{X} 10$ & NA & NA & NA & NA \\
\hline \multicolumn{5}{|l|}{$\ldots$} \\
\hline X69 & NA & NA & NA & NA \\
\hline X70 & $1.000 \mathrm{e}+00$ & $1.447 \mathrm{e}-14$ & $6.910 \mathrm{e}+13$ & $<2 \mathrm{e}-16^{* * *}$ \\
\hline $\mathrm{X} 71$ & NA & NA & NA & NA \\
\hline \multicolumn{5}{|l|}{$\ldots$} \\
\hline X99 & NA & NA & NA & NA \\
\hline
\end{tabular}

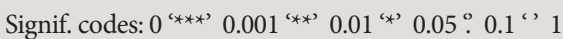

Residual standard error: $1.34 \mathrm{e}-14$ on 5 degrees of freedom.

Multiple R-squared: 1

Adjusted R- squared: 1

F-statistic: $4.98 \mathrm{e}+33$ on 10 and $5 \mathrm{DF}$

p-value: $<2.2 \mathrm{e}-16$

As it can be seen from the previous calculations, there are 10 independent variables: X1 to X9 and X70 that are significant for the dependent variable $(\mathrm{Y})$, which are described in the following table.

\begin{tabular}{|c|c|l|c|}
\hline $\begin{array}{c}\text { Significant } \\
\text { Independent } \\
\text { variables }\end{array}$ & \multicolumn{1}{|c|}{ IPC } & \multicolumn{1}{|c|}{ Code description } & \multicolumn{1}{|c|}{$\begin{array}{c}\text { Impact upon } \\
\text { the equation }\end{array}$} \\
\hline $\mathrm{X} 1$ & $\mathrm{~B} 33 \mathrm{Y} 10 / 00$ & Processes of additive manufacturing. & Positive \\
\hline $\mathrm{X} 2$ & $\mathrm{~B} 33 \mathrm{Y} 70 / 00$ & Materials specially adapted for additive manufacturing. & Positive \\
\hline $\mathrm{X} 3$ & $\mathrm{~B} 22 \mathrm{~F} 3 / 105$ & $\begin{array}{l}\text { Sintering only by using electric current, laser radiation or } \\
\text { plasma. }\end{array}$ & Negative \\
\hline $\mathrm{X} 4$ & $\mathrm{~B} 29 \mathrm{C} 67 / 00$ & Shaping techniques not covered by groups. & Negative \\
\hline $\mathrm{X} 5$ & B33Y30/00 & $\begin{array}{l}\text { Apparatus for additive manufacturing, details thereof or } \\
\text { accessories therefor. }\end{array}$ & Positive \\
\hline $\mathrm{X} 6$ & $\mathrm{~B} 33 \mathrm{Y} 50 / 02$ & Controlling or regulating additive manufacturing processes. \\
\hline $\mathrm{X} 7$ & $\mathrm{~B} 33 \mathrm{Y} 50 / 00$ & Data acquisition or data processing for additive manufacturing. & Negative \\
\hline $\mathrm{X} 8$ & $\mathrm{~B} 33 \mathrm{Y} 40 / 00$ & Auxiliary operations or equipment, e.g. for material handling. & Positive \\
\hline $\mathrm{X} 9$ & $\mathrm{~B} 28 \mathrm{~B} 1 / 00$ & Producing shaped articles from the material. & Negative \\
\hline $\mathrm{X} 70$ & G06T17/00 & 3D Modelling for computer graphics. & Positive \\
\hline
\end{tabular}


Table 6. IPCs that Belong to the Medical Science Category from the Top 99 IPCs (those most predominant) of the Third Dataset

\begin{tabular}{|c|c|c|c|}
\hline$\#$ & IPCs & Code description & $\begin{array}{l}\text { Number of } \\
\text { SPF }\end{array}$ \\
\hline 1 & A61L27/56 & Porous or cellular materials. & 155 \\
\hline 2 & A61L27/50 & Materials characterized by their function or physical properties. & 140 \\
\hline 3 & A61L27/54 & Biologically active materials, e.g. therapeutic substances. & 121 \\
\hline 4 & $\mathrm{~A} 61 \mathrm{~F} 2 / 28$ & Artificial substitutes or replacements for parts of the bones. & 108 \\
\hline 5 & $\mathrm{~A} 61 \mathrm{C} 13 / 00$ & Dental prostheses. & 102 \\
\hline 6 & A61L27/18 & Materials obtained otherwise than by reactions only involving carbon-to-carbon. & 102 \\
\hline 7 & $\mathrm{~A} 61 \mathrm{~F} 2 / 30$ & Joints prosthesis. & 101 \\
\hline 8 & A61B34/10 & Computer-aided planning, simulation or modelling of surgical operations. & 99 \\
\hline 9 & A61L27/58 & Materials at least partially resorbable by the body. & 85 \\
\hline 10 & A61L27/38 & Animal cells (for use in artificial skin). & 75 \\
\hline 11 & $\mathrm{~A} 61 \mathrm{C} 8 / 00$ & $\begin{array}{l}\text { Means to be fixed to the jaw-bone for consolidating natural teeth or for fixing dental prostheses } \\
\text { thereon; Dental implants; Implanting tools. }\end{array}$ & 70 \\
\hline 12 & A61L27/12 & Phosphorus-containing materials, e.g. apatite. & 61 \\
\hline 13 & A61B17/17 & Guides for drills. & 57 \\
\hline 14 & A61C7/00 & $\begin{array}{l}\text { Orthodontics, i.e. obtaining or maintaining the desired position of teeth, e.g. by straightening, } \\
\text { evening, regulating, separating, or by correcting malocclusions. }\end{array}$ & 56 \\
\hline 15 & $\mathrm{~A} 61 \mathrm{~F} 2 / 44$ & Prosthesis for the spine, e.g. vertebrae, spinal discs. & 49 \\
\hline 16 & A61L27/20 & Polysaccharides. & 47 \\
\hline 17 & A61L27/36 & Materials containing ingredients of undetermined constitution or reaction products thereof. & 46 \\
\hline 18 & A61L27/04 & Metals or alloys. & 43 \\
\hline 19 & A61L27/52 & Hydrogels or hydrocolloids. & 42 \\
\hline 20 & A61B5/00 & Measuring for diagnostic purposes; Identification of persons. & 41 \\
\hline 21 & A61B17/00 & Surgical instruments, devices or methods, e.g. tourniquets. & 40 \\
\hline 22 & $\mathrm{~A} 61 \mathrm{C} 9 / 00$ & Impression methods specially adapted for dental prosthetics; Impression cups therefore. & 40 \\
\hline 23 & A61L27/22 & Polypeptides or derivatives thereof. & 40 \\
\hline 24 & $\mathrm{~A} 61 \mathrm{~N} 5 / 10$ & X-ray therapy; Gamma-ray therapy; Particle-irradiation therapy. & 40 \\
\hline 25 & $\mathrm{~A} 61 \mathrm{C} 7 / 08$ & Mouthpiece-type retainers. & 39 \\
\hline 26 & A61F5/01 & $\begin{array}{l}\text { Orthopedic devices, e.g. long-term immobilizing or pressure directing devices for treating } \\
\text { broken or deformed bones such as splints, casts or braces. }\end{array}$ & 38 \\
\hline 27 & A61L31/14 & Materials characterized by their function or physical properties. & 38 \\
\hline 28 & A61B90/00 & $\begin{array}{l}\text { Instruments, implements or accessories specially adapted for surgery or diagnosis, e.g. for } \\
\text { luxation treatment or for protecting wound edges. }\end{array}$ & 37 \\
\hline
\end{tabular}

mation about the technology is scarce and there is no certainty about the commercial feasibility. In this case, the datasets show an important presence of scientific papers and patents, which convey the progress on the use of AM for the manufacturing of tablets and capsules. Among the advances displayed are the incorporation of multiple active pharmaceutical ingredients in a single tablet [Trenfield et al., 2018], the use of new AM processes [Mohammed et al., 2020], new formulations for fast, slow, and long-term drug delivery (biopolymers, etc.) [Trenfield et al., 2018], and new designs for tablets to help with pediatric patients' compliance [Palekar et al., 2019]. However, all these developments are still in an early scientific development stage and they have to go through clinical trials before they can be implemented into products.

- The T-intrauterine device is in stage 5 of the Trough of Disillusionment phase, where the product has over-inflated expectations that have been difficult to meet and, as a consequence, the product needs to readjust expectations in terms of real performance as well as commercial viability. In fact, only five scientific papers for $\mathrm{T}$ intrauterine devices were obtained, which presented 159 citations. On the other hand, its patenting activity showed a low score for market attractiveness (30/100), market coverage (46/100), and technology quality $(33.25 / 100)$, this means that the product has little relevance on the market and low significance for the patented feature of the product.

\section{Technological Areas of Medical Inventions of Products Made by AM}

The most predominant technological areas of research in this domain were determined through multiple linear regression analysis. For this aim, the dataset of 5,847 SPFs previously obtained with the specific IPC B33Y80/00 Products Made by Additive Manufacturing from 2004 to October 2019 was utilized. Specifically, 


\section{Box 2. Second Multiple Linear Regression Analysis}

$\mathrm{Y}($ dependent variable $)=$ the total number of patents published by year with the IPC B33Y80/00

X's (independent variables) $=$ the IPCs that belong to the Medical Science category from the top 99 IPCs (those most predominant in SPF)

Call:

$\operatorname{lm}($ formula $=\mathrm{Y} \sim \mathrm{X} 19+\mathrm{X} 25+\mathrm{X} 27+\mathrm{X} 27+\mathrm{X} 31+\mathrm{X} 34+\mathrm{X} 35+\mathrm{X} 37+\mathrm{X} 38+\mathrm{X} 42+\mathrm{X} 48+\mathrm{X} 51+\mathrm{X} 57+\mathrm{X} 59+\mathrm{X} 61$

$+\mathrm{X} 69+\mathrm{X} 71+\mathrm{X} 72+\mathrm{X} 74+\mathrm{X} 76+\mathrm{X} 78+\mathrm{X} 80+\mathrm{X} 81+\mathrm{X} 82+\mathrm{X} 83+\mathrm{X} 87+\mathrm{X} 88+\mathrm{X} 89+\mathrm{X} 94$, data $=$ For $\_$R)

Residuals:

$\operatorname{Min}=-0.40 ; 1 \mathrm{Q}=-0.40 ;$ Median $=0.00 ; 3 \mathrm{Q}=0.15 ; \operatorname{Max}=0.60$

Coefficients (22 not defined because of singularities)

\begin{tabular}{|c|c|c|c|c|}
\hline & Estimate & Std. Error & $\mathrm{t}$ value & $\operatorname{Pr}(>|t|)$ \\
\hline (Intercept) & 0.4000 & 0.1633 & 2.449 & $0.0368^{\star}$ \\
\hline $\mathrm{X} 19$ & 65.2167 & 0.4557 & 143.099 & $<2 \mathrm{e}-16^{* * *}$ \\
\hline $\mathrm{X} 25$ & -31.0281 & 0.2274 & -136.457 & $3.10 \mathrm{e}-16^{\star * *}$ \\
\hline $\mathrm{X} 27$ & 102.3690 & 0.6779 & 151.018 & $<2 \mathrm{e}-16^{* * *}$ \\
\hline $\mathrm{X} 31$ & -55.4928 & 0.6705 & -82.761 & $2.78 \mathrm{e}-14^{* * *}$ \\
\hline $\mathrm{X} 34$ & -17.6598 & 0.1019 & -173.229 & $<2 \mathrm{e}-16^{\star * *}$ \\
\hline $\mathrm{X} 35$ & -44.2762 & 0.3473 & -127.476 & $5.72 \mathrm{e}-16^{\star \star *}$ \\
\hline $\mathrm{X} 37$ & NA & NA & NA & NA \\
\hline $\mathrm{X} 38$ & NA & NA & NA & NA \\
\hline $\mathrm{X} 42$ & NA & NA & NA & NA \\
\hline $\mathrm{X} 37$ & NA & NA & NA & NA \\
\hline $\mathrm{X} 48$ & NA & NA & NA & NA \\
\hline $\mathrm{X} 51$ & NA & NA & NA & $\overline{\mathrm{NA}}$ \\
\hline $\mathrm{X} 57$ & NA & NA & NA & NA \\
\hline X59 & NA & NA & NA & NA \\
\hline X61 & NA & NA & NA & NA \\
\hline X69 & NA & NA & NA & NA \\
\hline X71 & NA & NA & NA & NA \\
\hline $\mathrm{X} 72$ & NA & NA & NA & NA \\
\hline X74 & NA & NA & NA & NA \\
\hline X76 & NA & NA & NA & $\mathrm{NA}$ \\
\hline X78 & NA & NA & NA & NA \\
\hline X80 & NA & NA & NA & NA \\
\hline X81 & NA & NA & NA & $\mathrm{NA}$ \\
\hline X82 & NA & NA & NA & NA \\
\hline $\mathrm{X} 83$ & NA & NA & NA & NA \\
\hline X87 & NA & NA & NA & NA \\
\hline X88 & NA & NA & NA & NA \\
\hline X89 & NA & NA & NA & NA \\
\hline X94 & NA & NA & NA & $\mathrm{NA}$ \\
\hline
\end{tabular}

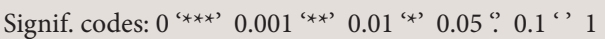

Residual standard error: 0.5164 on 9 degrees of freedom

Multiple R-squared: 1

Adjusted R- squared: 1

F-statistic: $5.586 \mathrm{e}+06$ on 6 and $9 \mathrm{DF}$

p-value: $<2.2 \mathrm{e}-16$

As it can be seen from the second calculations, there are six independent variables: X19, X25, X27, X31, X34, and X35 that are significant for the dependent variable $(\mathrm{Y})$, which are presented in the following table.

\begin{tabular}{|c|c|c|c|}
\hline $\begin{array}{l}\text { Significant } \\
\text { Independent } \\
\text { variables }\end{array}$ & IPC & Code description & $\begin{array}{l}\text { Impact in the } \\
\text { equation }\end{array}$ \\
\hline X19 & A61L27/56 & Porous or cellular materials. & Positive \\
\hline $\mathrm{X} 25$ & A61L27/50 & $\begin{array}{l}\text { Materials characterized by their function or physical } \\
\text { properties. }\end{array}$ & Negative \\
\hline $\mathrm{X} 27$ & A61L27/54 & Biologically active materials, e.g. therapeutic substances. & Positive \\
\hline $\mathrm{X} 31$ & $\mathrm{~A} 61 \mathrm{~F} 2 / 28$ & $\begin{array}{l}\text { Artificial substitutes or replacements for parts of the } \\
\text { bones. }\end{array}$ & Negative \\
\hline $\mathrm{X} 34$ & $\mathrm{~A} 61 \mathrm{C} 13 / 00$ & Dental prostheses. & Negative \\
\hline X35 & A61L27/18 & $\begin{array}{l}\text { Materials obtained otherwise than by reactions only } \\
\text { involving carbon-to-carbon. }\end{array}$ & Negative \\
\hline
\end{tabular}


Table 7. Stage of Development of Drug Delivery Products Produced by Means of Additive Manufacturing

\begin{tabular}{|c|c|c|c|c|c|c|c|c|c|c|}
\hline \multirow{3}{*}{\begin{tabular}{|c|}
$\begin{array}{c}\text { Application of Additive } \\
\text { Manufacturing } \\
\text { in Drug Delivery } \\
\text { Products }\end{array}$ \\
Product \\
\end{tabular}} & \multicolumn{9}{|c|}{ Hype cycle } & \multirow[t]{3}{*}{ Results } \\
\hline & \multicolumn{2}{|c|}{$\begin{array}{c}\text { Innovation } \\
\text { Trigger }\end{array}$} & \multicolumn{2}{|c|}{$\begin{array}{l}\text { Peak of Inflated } \\
\text { Expectations }\end{array}$} & \multicolumn{2}{|c|}{$\begin{array}{c}\text { Trough of } \\
\text { Disillusionment }\end{array}$} & \multicolumn{2}{|c|}{$\begin{array}{c}\text { Slope of } \\
\text { Enlightenment }\end{array}$} & \multirow{2}{*}{$\begin{array}{c}\begin{array}{c}\text { Plateau of } \\
\text { Productivity }\end{array} \\
\text { Stage } 9\end{array}$} & \\
\hline & Stage 1 & Stage 2 & Stage 3 & Stage 4 & \begin{tabular}{|l|} 
Stage 5 \\
\end{tabular} & Stage 6 & Stage 7 & Stage 8 & & \\
\hline Tablet & N/A & $\mathrm{V}$ & $\mathrm{V}$ & $\mathrm{V}$ & $\mathrm{X}$ & $\mathrm{X}$ & $\mathrm{X}$ & $\mathrm{X}$ & $\mathrm{X}$ & Stage 4 \\
\hline Capsules & N/A & $\mathrm{V}$ & $\mathrm{V}$ & $\mathrm{V}$ & $\mathrm{X}$ & $\mathrm{X}$ & $\mathrm{X}$ & $\mathrm{X}$ & $\mathrm{X}$ & Stage 4 \\
\hline Oral film & $\mathrm{N} / \mathrm{A}$ & V & $\mathrm{V}$ & $\mathrm{X}$ & $\mathrm{X}$ & $\mathrm{X}$ & $\mathrm{X}$ & $\mathrm{X}$ & $\mathrm{X}$ & Stage 3 \\
\hline T-intrauterine device & N/A & $\mathrm{V}$ & $\mathrm{V}$ & $\mathrm{V}$ & $\mathrm{V}$ & $\mathrm{X}$ & $\mathrm{X}$ & $\mathrm{X}$ & $\mathrm{X}$ & Stage 5 \\
\hline Suppository & N/A & $\mathrm{V}$ & $\mathrm{V}$ & $\mathrm{X}$ & $\mathrm{X}$ & $\mathrm{X}$ & $\mathrm{X}$ & $\mathrm{X}$ & $\mathrm{X}$ & Stage 3 \\
\hline Vaginal ring & $\mathrm{N} / \mathrm{A}$ & $\mathrm{V}$ & $\mathrm{V}$ & $\mathrm{V}$ & $\mathrm{X}$ & $\mathrm{X}$ & $\mathrm{X}$ & $\mathrm{X}$ & $\mathrm{X}$ & Stage 4 \\
\hline Wound dressing & N/A & $\mathrm{V}$ & $\mathrm{V}$ & $\mathrm{V}$ & $\mathrm{X}$ & $\mathrm{X}$ & $\mathrm{X}$ & $\mathrm{X}$ & $\mathrm{X}$ & Stage 4 \\
\hline Facemask & N/A & $\mathrm{V}$ & $\mathrm{V}$ & $\mathrm{X}$ & $\mathrm{X}$ & $\mathrm{X}$ & $\mathrm{X}$ & $\mathrm{X}$ & $\mathrm{X}$ & Stage 3 \\
\hline Microneedle & N/A & V & V & V & X & X & X & X & X & Stage 4 \\
\hline
\end{tabular}

the analysis was developed with the IPC B33Y80/00 Products Made by Additive Manufacturing as a dependent variable and the 28 IPCs with most SPF records that belong to the Medical Science category of the third dataset (see Box 2) as independent variables. Results from this study show that medical science where additive manufacturing processes have been incorporated focused on: A61L27/56 porous or cellular materials and A61L27/54 biologically active materials, e.g. therapeutic substances.

The IPC A61L27/56 porous or cellular materials recorded a total of 155 simple patent families. As Mazur et al establishes "Cellular materials are formed by periodic or stochastic arrangements of open or closed cell types, with either two-dimensional cell configurations (such as honeycomb) or three-dimensional polyhedral layouts (such as lattice structures)" [Mazur et al., 2017]. This type of material is highly appreciated fot its unique mechanical properties as a low volume percentage of solids and small cell size, which allow for freedom of designs beyond the capability of solid materials [Mazur et al., 2017; Ulm, 2001; Leary, 2018] which is so valuable for additive manufacturing purposes. Additionally, some studies have demonstrated that the control of these periodic cellular structures can help in tailoring the drug release [Mazur et al., 2017].

The IPC A61L27/54 biologically active materials revealed 121 simple patent families. This kind of material comprises "materials that elicit a specific biological response at the interface of the material, which results in the formation of a bond between the tissues and the material" [Hench, 2005]. They provide superior advantages to diverse therapeutic applications for wound management, including the use of implantable medical devices, and the use of synthetic tissue grafts ${ }^{11}$, this explains its importance for drug delivery products made by additive manufacturing.

\section{Figure 1. Hype Cycle of Drug Delivery Products Produced by Means of Additive Manufacturing}

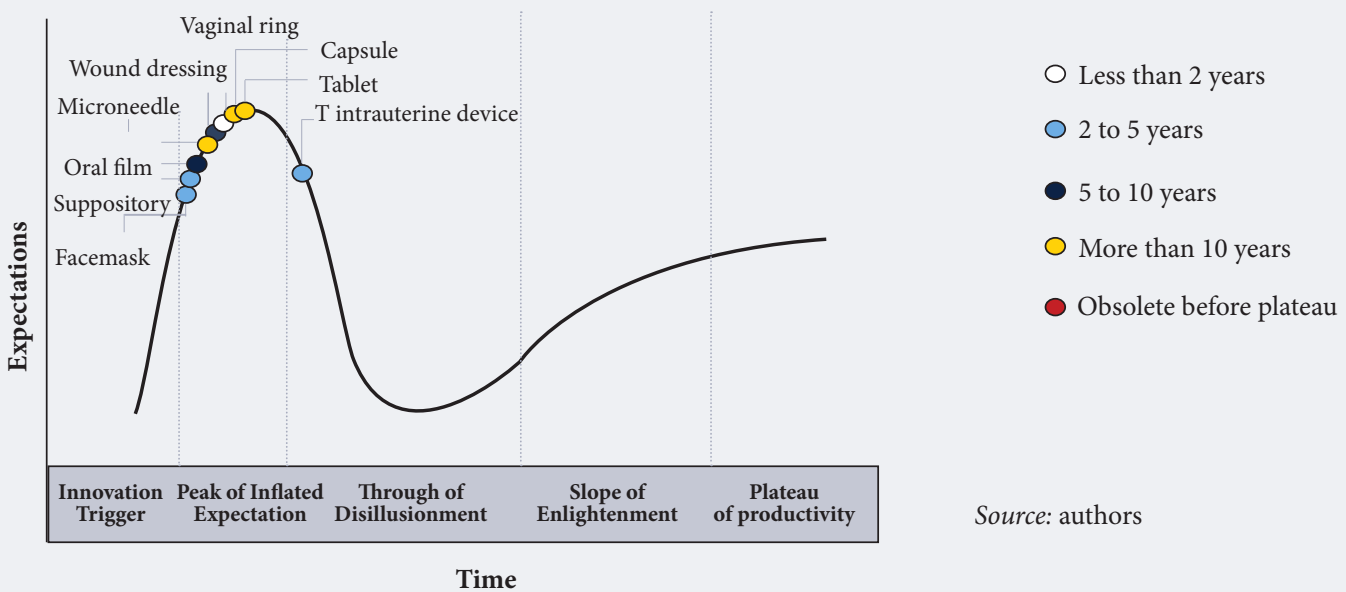

${ }^{11}$ Available at: https://www.medtech.plus/en/trend-topics/biologically-active-materials, accessed 23.11.2019. 
Through the years, additive manufacturing has grown significantly [Basiliere et al., 2018]. Its evolution depends mainly upon the quality of the material to be printed (ink quality) and on the accuracy of the printing process [Goyanes et al., 2019]. Recently, advances in technology have brought new opportunities for product development in many areas [Lupeanu et al., 2010]. Specifically, multiple linear regression analysis shows the following as new directions for medical inventions of products made with AM: porous or cellular materials (IPC A61L27/56) and biologically active materials (IPC A61L27/54). As mentioned in the fourth stage of the methodology, products related to pharmaceutical and drug delivery are included in the medical science category. For this reason, both materials (porous or cellular materials and biologically active materials) can be considered new trends for drug delivery products made with AM as well.

To give a more specific idea of the presence of additive manufacturing in inventions for drug delivery, Table 8 shows examples of patents (all having one of both previous IPCs) that demonstrate a large amount of demand in the health industry for 1) bone repair, that includes inventions such as a scaffold that allows antibiotic infiltration, and a repairing a bracket with antibacterial properties and 2) cell transportation, which comprises inventions such as scaffolds for cells implanted that release active compositions, and scaf- folds where bioactive composition controls the egress of a resident cell.

\section{Conclusions}

Additive manufacturing (AM) is gaining increasing interest in the pharmaceutical industry, specifically for reconfiguring Drug Delivery Systems (DDSs) and Drug Testing Systems (DTSs) [Jamroz et al., 2018]. AM is expected to bring about major changes and transform the pharmaceutical industry by enabling the development of novel product designs, methods, applications, materials, and manufacturing processes.

Competitive and Technology Intelligence (CTI) is an important methodology for analyzing new technologies, adding value to strategic decisions for research, development, and innovation. This study presented the application of a CTI to uncover the maturity of drug delivery products created with additive manufacturing and determine the principal technology areas in medical inventions of products made using additive manufacturing. For this purpose, a hype cycle and multiple linear regression analysis were executed involving scientific documents and patents from Scopus and the PatSnap platform.

The results of the hype cycle analysis showed that oral films, suppositories, and facemasks are located in stage 3 of the Peak of Inflated Expectation phase. There is no evidence of patent activity for these products yet, the

Table 8. Presence of Additive Manufacturing in Drug Delivery Inventions: Patent Examples for IPC A61L27/56 and IPC A61L27/54

\begin{tabular}{|c|c|c|}
\hline IPC & Patent (Organisation, Country, Year) & Abstract of Patent \\
\hline \multicolumn{3}{|c|}{ Inventions for Bone Applications } \\
\hline A61L27/56 & $\begin{array}{l}\text { US20150150681A1 - Tissue repair } \\
\text { devices and scaffolds } \\
\text { (New York University, USA, } \\
\text { 2015) }\end{array}$ & $\begin{array}{l}\text { The present invention relates to multiphasic, three-dimensionally printed } \\
\text { tissue repair devices or scaffolds that are useful for promoting bone growth } \\
\text { and treating bone fracture, defect, or deficiency. The scaffold has a porous } \\
\text { bone ingrowth area containing interconnected struts surrounded by a } \\
\text { microporous shell. The center of the scaffold may be empty and may serve as } \\
\text { a potential marrow space. The porous ingrowth structure may be infiltrated } \\
\text { with a soluble filler or carrier, such as, for example, calcium sulfate which may } \\
\text { be infiltrated with one or more antibiotics, a growth factor, a differentiation } \\
\text { factor, a cytokine, a drug, or a combination of these agents. }\end{array}$ \\
\hline A61L27/54 & $\begin{array}{l}\text { CN106729988A - } \\
\text { 3D printing bone repairing bracket with } \\
\text { antibacterial property and preparation } \\
\text { method of 3D printing bone repairing } \\
\text { bracket } \\
\text { (Guangdong Taibao Medical Devices } \\
\text { Technology Research Institute Co. Ltd., } \\
\text { China, 2017) }\end{array}$ & $\begin{array}{l}\text { This invention belongs to the technical field of biomedical engineering, and } \\
\text { particularly relates to skin wound dressing preparation, and involves a 3D } \\
\text { printing bone repairing bracket with antibacterial property and a preparation } \\
\text { method for the 3D printing bone repairing bracket. This 3D printing } \\
\text { bone repairing bracket has a multi-layer column-shaped structure and a } \\
\text { good three-dimensional pore structure and consists of polycaprolactone, } \\
\text { polydopamine, and antibacterial peptide LL37. Also, it is performs well in } \\
\text { biocompatibility, in antibacterial property, and in osteogenic capability and } \\
\text { bone conduction capability, further, it has the function of promoting new } \\
\text { bone tissue growth at bone coloboma parts. }\end{array}$ \\
\hline \multicolumn{3}{|c|}{ Inventions for Cell Transportation } \\
\hline A61L27/56 & $\begin{array}{l}\text { US20190254959A } 1 \text { - Cell associated } \\
\text { scaffolds for the delivery of agents } \\
\text { (Australian Foundation for Diabetes } \\
\text { Research, Australia, 2019) }\end{array}$ & $\begin{array}{l}\text { The present invention relates to the use of scaffolds to enhance the viability } \\
\text { of cells implanted in the integumentary system such that the cell may release } \\
\text { an agent. The scaffold is capable of protecting the cell, as well as allowing for } \\
\text { adequate nutrient delivery at the implant site through vascularization in and } \\
\text { around the scaffold. }\end{array}$ \\
\hline A61L27/54 & $\begin{array}{l}\text { US10149897 — Scaffolds for cell } \\
\text { transplantation } \\
\text { (Harvard University, USA, 2018) }\end{array}$ & $\begin{array}{l}\text { A device that includes a scaffold composition and a bioactive composition } \\
\text { with said composition being incorporated into or coated onto the scaffold } \\
\text { such that the scaffold composition and/or a bioactive composition controls } \\
\text { the egress of a resident cell or progeny thereof. The devices mediate the active } \\
\text { recruitment, modification, and release of host cells from the material. }\end{array}$ \\
\hline
\end{tabular}


technology information is still limited, and there also few scientific papers. They have great potential as drug delivery products, but they may need more investment in research and development, especially the face masks which are used for scar treatment. Perhaps some of the lack of investment in these technologies is due to limited evidence of cost-benefit balance and their need for personalization.

Tablets, capsules, vaginal rings, wound dressings, and microneedles are in stage 4 of the Peak of Inflated Expectations phase, being the stage with the most publications and citations from all the categories. Media confer them high expectations. However, their technology is still in an early stage of development. The normal time for the development of a pharmaceutical product from bench to clinic is usually between 10 15 years [Freeman, Dervan, 2011]. From this group, tablets, capsules, and wound dressings are the products with more expectations and research studies. They have the most important role in drug delivery products fabricated with AM, big pharmaceutical companies such as GlaxoSmithKline and Pfizer are already involved in researching this type of product [Clark et al., 2017; Trenfield et al., 2018].

The $T$ intrauterine device is in stage 5 of the Trough of Disillusionment phase, where the products need to readjust expectations, meet performance standards, and commercial viability. Since the majority of these kinds of products follow a standard design, improvements are mainly focused on their active pharmaceutical ingredients including their manufacturing process.

Globally, the results of the hype cycle show that drug delivery products are located mostly in the Peak of Inflated Expectations phase, this finding is also supported by the Gartner report "Predicts 2019: 3D printing accelerates, while $4 \mathrm{D}$ printing is getting started" [Basiliere et al., 2018]. As mentioned previously, AM will make a significant contribution to changing the traditional pharmaceutical industry providing unique advantages such as the development of personalized medicine, control of drug release as well as the design of products with multiple active pharmaceutical ingredients [Basiliere et al., 2018; Jamroz et al., 2018; Goole, Amighi, 2016]. Even though advances are very promising, drug delivery products need to evolve more to obtain better results, meet standards, improve prices, and gain market penetration [Basiliere et al., 2018]. Key challenges that need to be addressed are the lack of FDA (Food and Drug Administration) and GRAS (Generally Recognized as Safe) approved materials that can be used for pharmaceuticals and 3D printed products, manufacturing times, scale-up, process stability, and price [Guzzi, Tibbitt, 2020].

With regard to the multiple linear regression analysis, outcomes show that products made by additive manufacturing belonging to the Medical Science category related to drug delivery are focused on: 1) porous or cellular materials (A61L27/56) and 2) biologically active ma- terials, e.g. therapeutic substances (A61L27/54). Both materials groups are very important to drug delivery product development. Tablets where the release is controlled depending on the porosity are a good example.

Moreover, after investigating the details of the retrieved scientific papers and patents and validating them with experts, Vat Photopolymerization and Material Extrusion were identified as the two AM technologies that have the highest impact upon the pharmaceutical applications made by AM, especially Fused Deposition Modeling (FDM) processes that belong to Material Extrusion technology. Perhaps this is due to the recent expiration of the FDM patent, allowing more companies to develop and use FDM printers at more accessible prices. Materials such as cellular materials and biologically active materials were also identified as having a high impact upon the pharmaceutical products made by AM.

In conclusion, products for drug delivery created with additive manufacturing have many advantages but they are still in development as can be seen from the hype cycle analysis. Scientific documents, patents, and expert views analysis of this research indicate that its evolution strongly depends upon the quality of the materials to be printed and the accuracy of the processes. Initial clinical applications of personalized pharmaceuticals have demonstrated that there are benefits that arise from customization [Goyanes et al., 2019]. However, in many clinical settings, off-the-shelf pharmaceuticals will likely suffice. Therefore, it is important to understand when customization is appropriate.

Additionally, the regulatory approval for AM of precision medicine is not clear. The materials used to fabricate the devices should be approved following standard routes; yet, the method by which the final devices themselves can be approved is less obvious. The FDA and other regulatory bodies have provided some advice on how AM can be integrated into the approval process. However, a full regulatory path has not been defined. Thus, this makes it harder for companies to decide whether they will invest in these technologies.

In summary, the results of this study demonstrate the current state of scientific and technology behavior in the innovative domain of drug delivery and medical science where AM is present. It helps researchers make decisions that aim to incorporate new technologies such as AM. This study shows that there is a great amount of interest and R\&D development in this type of product, but the technology is still in an early stage and has not passed through the disillusionment phase, which could be decisive in terms of its mass adoption

This research was supported by the School of Engineering and Sciences of Tecnologico de Monterrey and by the National Council of Science and Technology (CONACYT) through a graduate scholarship. Laura Ruiz-Cantu was also funded by the Engineering and Physical Sciences Research Council grant $E P / P 031684 / 1$. 


\section{References}

Basiliere P., Berntz I., Burt M., Gupta A., Jones M., Kutnick D., Halpern M., Shanler M. (2018) Predicts 2019: 3D Printing accelerates, while 4D Printing is getting started, Stamford, CT: Gartner Research.

Ching-Chiang Y., Yi-Fan C. (2018) Critical success factors for adoption of 3D printing. Technological Forecasting and Social Change, vol. 132, pp. 209-216.

Clark E., Morgan R., Alexander, D., Irvine C., Roberts M., Wallace S., Jae Y., Richard J., Hague C., Wildman R. (2017) 3D Printing of Tablets Using Inkjet with UV Photoinitiation. International Journal of Pharmaceutics, vol. 529, no 1-2, pp. 523-530.

Colakogly T. (2011) The problematic of competitive intelligence: How to evaluate and develop competitive intelligence? Procedia Social and Behavioral Sciences, vol. 24, pp. 1615-1623.

Dedehayir O., Steinert M. (2016) The hype cycle model: A review and future directions. Technological Forecasting \& Social Change, vol. 108, pp. 28-41.

Evans W., Mary V. (2004) Moving towards Individualized Medicine with Pharmacogenomics. Nature, no 429 (6990), pp. 464-468.

Freeman M.W., Dervan A.P. (2011) The path from bench to bedside: Considerations before starting the journey. Journal of Investigative Medicine, vol. 59, no 5, pp. 746-751.

Gartner Research (2018) Understanding Gartner's Hype Cycle. Available at: https://www.gartner.com/en/documents/3887767, accessed 15.11.2019.

Goole J., Amighi K. (2016) 3D printing in pharmaceutics: A new tool for designing customized drugs delivery systems. International Journal of Pharmaceutics, vol. 499, no 1-2, pp. 376-394.

Goyanes A., Fina F., Martorana A., Sedough D., Gaisford S., Basit A.W. (2017) Development of modified release 3D printed tablets with pharmaceutical excipients using additive manufacturing. International Journal of Pharmaceutics, vol. 527, no 1-2, pp. 21-30.

Goyanes A., Madla C.M., Umerji A., Duran G., Giraldez J.M., Lamas M.J., Gonzalez M., Taherali F., Sanchez-Pintos P., Couce M.L., Gaisford S., Basit A.W. (2019) Automated therapy preparation of isoleucine formulations using 3D printing for the treatment of MSUD: First single-centre, prospective, crossover study in patients. International Journal of Pharmaceutics, vol. 567, art. 118497. DOI: 10.1016/j.ijpharm.2019. Available at: https://pubmed.ncbi.nlm.nih.gov/31279771/, accessed 12.04.2020.

Groll J., Burdick J., Cho D., Derby B., Gelinsky M., Heilshorn S., Jungst T., Malda J., Mironov V., Nakayama K., Ovsianikov A., Sun W., Takeuchi S., Yoo J., Woodfield T. (2018) A definition of bioinks and their distinction from biomaterials inks. Biofabrication, vol. 11, no 1, art. 013001. DOI: 10.1088/1758-5090/aaec52. Available at: https://pubmed.ncbi.nlm.nih. gov/30468151/, accessed 10.02.2020.

Guzzi E.A., Tibbitt M.W. (2020) Additive Manufacturing of Precision Biomaterials. Advanced Materials, vol. 32, no 13, art. 1901994. DOI: 10.1002/adma.201901994. Available at: https://pubmed.ncbi.nlm.nih.gov/31423679/, accessed 07.02.2020.

Hamburg M. (2013) Paving the Way for Personalized Medicine: FDA's Role in a New Era of Medical Product Development, Washington, D.C.: US FDA.

Hench L. (2005) Repair of skeletal tissues. Biomaterials, Artificial Organs and Tissue Engineering (eds. L. Hench, J. Jones), Sawston (UK): Woodhead Publishing, pp. 119-128.

Jamroz W., Szafraniec J., Kurek M., Jachowicz R. (2018) 3D printing in pharmaceutical and medical applications - Recent achievements and challenges. Pharmaceutical Research, vol. 35, pp. 176-198.

Leary M. (2018) Design of titanium implants for additive manufacturing. Titanium in Medical and Dental Applications (eds. F.H. Froes, M. Qian), Sawston (UK): Woodhead Publishing, pp. 203-224.

Lente H., Spitters C., Peine A. (2013) Comparing technological hype cycles: Towards a theory. Technological Forecasting and Social Change, vol. 80, pp. 1615-1628.

Liam S., Kathuria H., Yao J., Kang L. (2018) 3D printed drug delivery and testing systems - A passing fad or the future? Advanced Drug Delivery Reviews, vol. 132, pp. 139-168.

Lupeanu M., Neagu C., Neacsu A. (2010) Current trends in product development. Proceedings of the 4th conference on European computing conference (eds. M. Grigoriu, V.M. Mladenov), Stevens Point: WI: World Scientific and Engineering Academy and Society (WSEAS), pp. 94-99.

Mazur M., Leary M., McMillan M., Sun S., Shidid D., Brandt M. (2017) Mechanical properties of Ti6Al4V and AlSi12Mg lattice structures manufactured by Selective Laser Melting (SLM). Laser Additive Manufacturing: Materials, Design, Technologies, and Applications (ed. M. Brandt), Sawston (UK): Woodhead Publishing, pp. 119-161. 
Mohammed A., Elshaer A., Sareh P., Elsayed M., Hassanin H. (2020) Additive Manufacturing technologies for drug delivery applications. International Journal of Pharmaceutics, vol. 580, art. 119245. DOI: 10.1016/j.ijpharm.2020.119245. Available at: https://pubmed.ncbi.nlm.nih.gov/32201252/, accessed 27.06.2020.

O’Leary D. (2008) Gartner's hype cycle and information system research issue. International Journal of Accounting Information Systems, vol. 9, pp. 240-252.

Palekar S., Nukala P.K., Mishra S.M., Kipping T., Patel K. (2019) Application of 3D printing technology and quality by design approach for development of age-appropriate pediatric formulation of baclofen. International Journal of Pharmaceutics, vol. 556, pp. 106-116.

Palo M., Hollander J., Suominen J., Yliruusi J., Sandler N. (2017) 3D printed drug delivery devices: Perspectives and technical challenges. Expert Review of Medical Devices, vol. 14, no 9, pp. 685-696.

Rajgor N., Bhaskar V., Patel M. (2011) Implantable drug delivery systems: An overview. Systematic Reviews in Pharmacy, vol. 2, no 2, pp. 91-95.

Rodriguez M., Villarreal D., Alvarez M., Trujillo G. (2019) Analysis of the knowledge landscape of three-dimensional bioprinting in Latin America. International Journal of Bioprinting, vol. 5, no 2-3, pp.16-22. DOI: 10.18063/ijb.v5i2.3.240

Sadée W., Dai Z. (2005) Pharmacogenetics/Genomics and Personalized Medicine. Human Molecular Genetics, vol. 14, no 2, pp. 207-214.

Sadia M., Sosnicka A., Arafat B., Isreb A., Ahmed W., Kelarakis A., Alhnan M.A. (2016) Adaptation of pharmaceutical excipients to FDM 3D printing for the fabrication of patient-tailored immediate release tablets. International Journal of Pharmaceutics, vol. 513, pp. 659-668.

Trenfield S.J., Awad A., Goyanes A., Gaisford S., Basit A.W. (2018) 3D printing pharmaceuticals: Drug development to frontline care. Trends in Pharmacological Sciences, vol. 39, no 5, pp. 440-451.

Ulm F.-J. (2001) Construction: Cellular Materials. Encyclopedia of Materials: Science and Technology (2nd ed.) (eds. K.H. Jürgen-Buschow, R.W. Cahn, M.C. Flemings, B. Ilschner, E.J. Kramer, S. Mahajan, P. Veyssière), Amsterdam: Elsevier, pp. 1570-1574. Available at: https://doi.org/10.1016/B0-08-043152-6/00280-1, accessed 17.05.2020.

Wang P., Zhuo X., Chu W., Tang X. (2017) Exenatide-Loaded Microsphere/Thermosensitive Hydrogel Long-Acting Delivery System with High Drug Bioactivity. International Journal of Pharmaceutics, vol. 528, no 1-2, pp. 62-75.

White G., Samuel A. (2019) Programmatic advertising: Forewarning and avoiding hype cycle failure. Technological Forecasting and Social Change, vol. 144, pp. 157-168. 